\title{
RADICAL TEACHPR
}

A SOCIALIST, FEMINIST, AND ANTI-RACIST JOURNAL ON THE THEORY AND PRACTICE OF TEACHING

\section{We Don't Need Your Permission: The Era of Non- Affiliated Student Activism}

by Rebecca Elizabeth Dolhinow

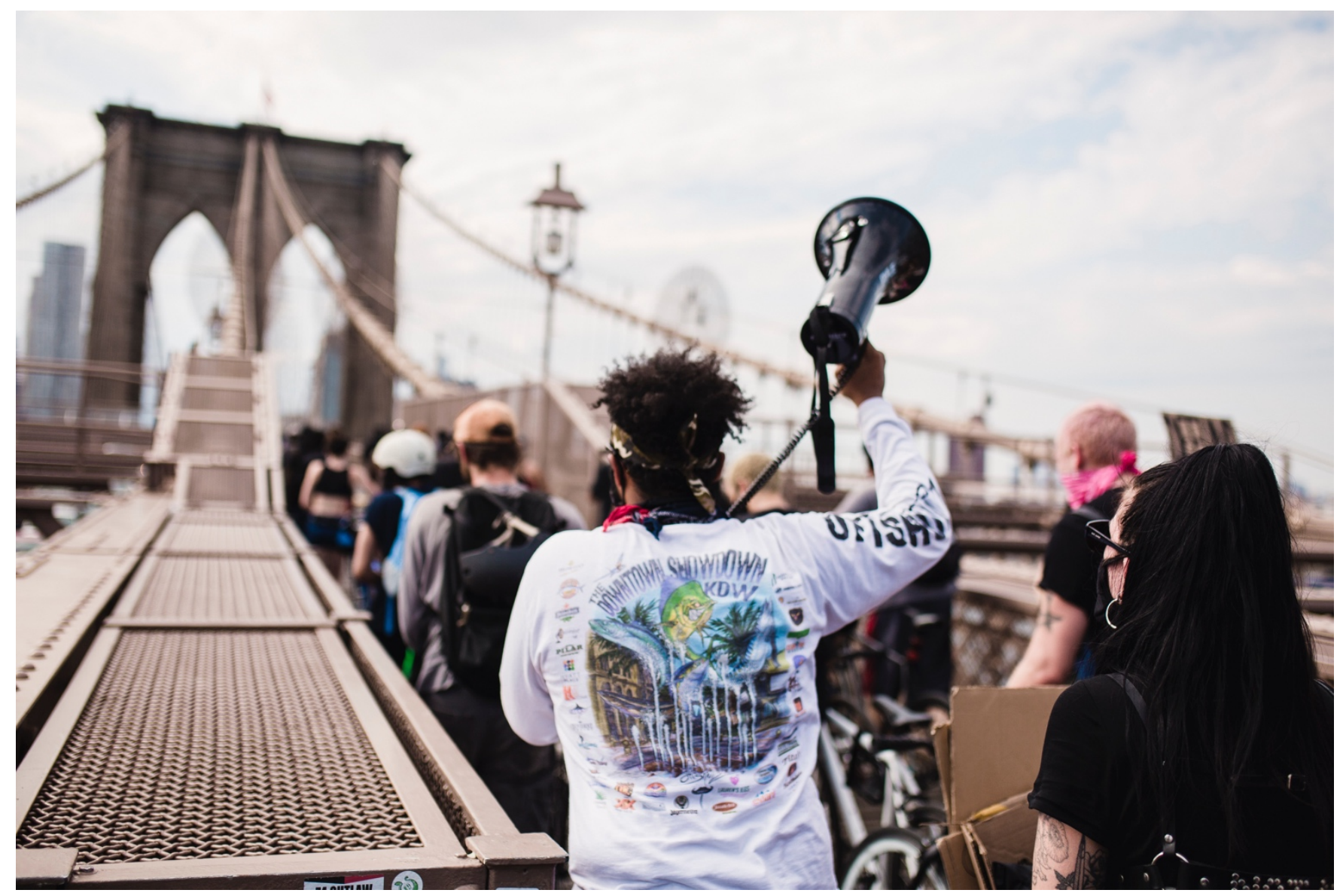

PHOTO BY LIFE MATTERS, PEXELS.COM 
What does it look like when tribes come together to push back? ...it's going to be very interesting to see this happen on college campuses. Since the sixties, it's just like, we have pockets of activism, but not revolution.

-Amy, activist with the group

T he neoliberal The neoliberal focus on education as a product for sale is commonplace in higher education today. My own institution refers to itself as "the marketplace of ideas." Make no mistake, the stress is on the market in "marketplace": the selection of the most profitable classes is stressed over student interests and educational goals. This move toward education for consumption puts both educators and students in increasingly precarious positions. Faculty become service providers that work to increase the statistics that lead to better funding and enrollments. Students get caught in a system that wants them to be consumers rather than critical thinkers and active stakeholders of their own educations. In response to these changes in higher education, an upsurge in student activism against the corporate university and its agenda has arisen as well as a corresponding crackdown on activism from universities. This article examines the response of student activist groups in California, particularly in the California State University system, to the corporatization of their universities. Drawing on thirteen years of ethnographic research, I use the words and actions of student leaders to discuss the administrative commodification of activism, and the choice of radical student activists to move outside the university system to best confront these issues.

As Radical Teacher readers will be aware, the neoliberal corporate university, like any good corporation, is all about control (Bousquet 2008). This exertion of control can be seen in the growth of rules and regulations, the increase in organizational divisions, administrative bloat, and the committee and assessment work these new divisions create for faculty and staff (Ginsberg 2011; Newfield 2016). Most of the changes that accompany the corporatization of the neoliberal university work for better control of employees and students. In this situation, where does radical student activism fit in, if it does at all? And how does such activism evolve in the corporate university in order to stay alive?

The answer the corporate university would offer is nowhere. Student activism is not welcome on campuses, at least if it is student lead and directed. The university is willing to tolerate the soft "activism" it fosters in its own social justice curriculum, but not the kind of activism that the student groups I studied propose and practice (Dolhinow 2017). In order to control student activism, university administrations work hard to enclose or coopt the student activist spaces that threaten them. In response, many radical activist groups, with a deeply analytical understanding of their relationship to the power structure of the corporate university, move off campus to organize and build coalitions.

The student activists in my research are primarily young people of color who find it difficult to identify with the kind of social justice and social change presented in many university-run student spaces on their campuses. (Of the eight students quoted in this article, six are students of color and three identify as gender queer.) These activists find supervised spaces often ignore or offer only superficial analyses of their lived experiences. As a result, they find it easier to create community and support structures outside of traditional campus student organizations. From these outside spaces, they can create activist communities that honor their personal and historical views of social justice organizing. This outside position also allows them a freedom "registered" college and university student groups do not have. At the same time, however, it limits them in terms of campus resources and can lead to blacklisting by administration and faculty who believe they are dangerous if they cannot be held accountable.

The radical student groups fighting for changes at their institutions challenge the system using controversial and militant means. As part of this, they exhibit a willingness to address issues relating to their university that other student groups are not willing to take on for fear of being shut down or made an example of by the administration. They disrupt board of trustees' meetings, rally outside the Chancellor's house, and petition for a vote of no confidence in their university President. This is how one young activist describes his relationship to the President of his institution,

I've gone up to, like, the Board of Trustees and called her [President] shady for, like, the way she pulled off the fee increase... exposing information like that, that wasn't supposed to be, like said out loud and stuff like that ... in front of the twenty-three Presidents [of the Cal State System] and...like the Trustees. - Ramon

These student radicals are also more likely to reference oppression and their opposition to hegemonic power structures such as capitalism. In the words of one activist, his group is "very resistance led."

Many of these activists already view themselves as outside the higher education system. This sentiment can be seen here in a passage from a zine produced by one of the groups in this study.

For many young people of color and the poor, public education was an obstacle course; there was zero tolerance for any wrong move, any slip up, any mistake. Our socioeconomic condition only added to the obstacles we faced in the classroom; hunger distracted us, the streets or police killed us. Higher education for us was our ticket out of poverty and up the socioeconomic ladder. When we finally arrived, however, we were given a choice: pay with the money you don't have or go back home. We knew little about the implications and ramifications of the debt we would inquire [sic]. For people of color and the poor, there was no choice. In our attempts to improve our present condition, we signed and sold away our future.

In this passage, a shared understanding of the material relationships between higher education and the oppression of capitalism are clear. This shared understanding is used to both attract new members to the organization and to situate their mutual experiences as already outside a system that 
does not serve them. One common idea that unites the radical groups is their deeper understanding of how the corporate university works. At every meeting I attended, and in every group interview I conducted, at least one member linked their work against their corporate university to anti-capitalist work. Many of these radical student activists understand capitalism as the root of their oppressions and share this understanding through their activism on campus and social media.

\section{Why Position is Power}

At the heart of my work on student activism is a desire to understand how student activists, and activists more generally, produce the spaces in which they work. While this project developed over the last decade, it became clear to me that the production of autonomous student activist spaces on campuses was in danger, particularly on large state campuses. These spaces, which I term Commons Counter Spaces because they function like commons providing a meeting area for students who share goals, values, and experiences to pool resources and work collectively (Bollier 2014, Dolhinow 2017), proved to be too challenging and unpredictable to the neoliberal university. And so, they had to be controlled. The demise of the Commons Counter Space comes in several forms, devised and implemented by the administrations on the activists' campuses. If Commons Counter Spaces offer students a place to organize their activist campaigns and support each other in their growth as radical activists, then the spaces universities offer in place of Commons Counter Spaces do essentially the opposite (while pretending to do the same).

Many universities in the process of enclosing student activist commons replace them with their own watered down and tame versions of civic or community engagement toward social justice. Within these spaces of activist tourism, universities attempt to control and direct dissent on their campuses while commodifying the elements of social justice for easy consumption and university credit. By the logic of the corporate university, this consumer-friendly version of social justice activism is much more palatable for incoming students, their parents, and funders (Dolhinow 2020). In her work on youth organizing in communities of color, Soo Ah Kwon (2013) argues that youth activism "is implicated in an affirmative governmentality, which posits poor youth of color as potentially worthy subjects of improvement through their participation in community programs aimed at helping them to become better citizen-subjects" (p. 126). The community programs she describes in her ethnographic work do just what the commodified social justice programs and sites of the corporate university do: tame activism and direct youth dissent into actions and avenues deemed harmless to the neoliberal system.

Several of the groups with which I work find the administrative cooptation of social justice spaces creates fewer places on campus in which they feel comfortable, or even safe, organizing and meeting. Two unregistered groups that take part in controversial work questioning the actions and policies of their universities discussed the problems with cross cultural centers. These groups see the recent trend toward consolidating identity-based centers into one space as a move to control their individual centers and separate them from their roots in academic disciplines, which are often seen as more political and harder to control. One group, a chapter of OutSpoken, a state-wide organization that fosters radical activists, named the new cultural center complex on their campus "The Diversity Museum" due to its open layout. The activists in this group feel the space is designed for supervision. They will not meet there because they feel spied on when administrative employees can walk through and overhear their conversations at any time. Similarly, Commit to Campus Justice, whose focus is the elimination of the unjust and racist polices of their university, had this to say about working in campus-based cultural center spaces:

...what we want most in those meetings is privacy, the privacy to say what we need to without having someone's co-worker or their supervisor or their boss hear. So, when we have been speaking in, like, the cultural centers it's always been hushed, and it's always been a bit more reserved in how we actually go about what we're doing. ...that space is not one we feel safe to speak freely in. -Jackson

Commit to Campus Justice and OutSpoken are only two of the half dozen groups that expressed increasing problems finding spaces to organize on campus. The solutions I heard ranged from meeting outdoors on campus far enough away from buildings to not be overheard or in parks or coffee spots near campus. For Commit to Campus Justice other options exist as well but are not easy, as one member explains:

We never met as a group in one of those spaces [cultural centers or other student union spaces]. It's been someone's dorm, for the most part. I work in a research lab in the [blank] department and I was able to use my lab room for two of our meetings. So, it's really--it's burdensome for the person whose dorm it is, right? And all of their roommates, so we try to find other spaces, but it's not easy and you've got to get a key, you've got to, like, figure it all out each time and you have to tell people where it's going to be, so it's not easy to organize from a logistical perspective. -Greg

Without institutional support and space to gather in person, these student groups look to each other for community and backup. They work as a network to push each other's campaigns and share ideas and strategies. Ron is a student organizer with OutSpoken; he believes broad coalitions across groups are the way forward for radical student activism:

I would hope that a cohesive coalition across different campuses do exist and [OutSpoken] does have that potential. ... I know a lot of people in [OutSpoken] do share how promising it is for them because sometimes they feel very secluded in like in their campuses... And so, I think for a lot of [OutSpoken]... members, seeing people across, like, the state that share the same ideas and share the same work is very helpful to them. That kind of like boosts them to do the work. -Ron 
While the most fruitful coalition in which Ron takes part is the OutSpoken network, he also works hard to make contacts and develop relationships with other radical groups in California and beyond. Recently Ron's chapter of OutSpoken was put in contact with a new non-affiliated student organization on the East Coast that is trying to address issues of racism and discrimination they believe their institution downplays while pretending to respond through "diversity" campaigns. These student activists do not believe this is a problem they can take on from within the existing system without the aid of a larger coalition of social activists.

\section{To Register or Not}

For OutSpoken, ...we didn't want to do a hierarchy. So, when you register you have to have a president, a vice president, and a treasurer. And that seems like a lot of problems especially in our beliefs and our values. How we run OutSpoken, where no one is higher than each other. -Emma

Emma is a current leader in OutSpoken and for her one of the key benefits of their position outside the regulated university system is their ability to avoid the hierarchical forms of organization required by university administrations. As Emma describes, most university systems impose a hierarchical structure on student groups when they require "officers" to be named. According to Emma, in the student organizations on campus that are registered, "[e]ven if you say 'oh, we won't have this a hierarchy' when it comes down to it, it always comes out when someone is like, 'oh well, I'm the President' or 'I run this, and I run that'." OutSpoken understands that power, even in title, changes the relationships between people just as it changes one's vision and experience of the world. Emma expresses here an awareness of the traditional, hierarchical, and often oppressive power relations the corporate university represents and imposes on those that work within it. Emma's chapter of OutSpoken, like others I met, found these power relations offensive and antithetical to the kind of university and society they sought. For them a position outside university affiliation and registered groups is the best possible place from which to work with integrity to oppose the hegemonic systems in which they find themselves every day.

On most campuses, student organizations must be registered with the Division of Student Affairs in order to function legitimately. When I began working with student activists the process of registering as a student group was simple, involving a form with a signature, a basic "constitution" or mission statement, and a letter of support from an advisor. Today, on my campus and many others, the process is fully digitized through an online system that not only intakes the general information on the group and its required hierarchical leadership but also disseminates this information to many offices across campus that previously were not part of the registration process. To continue functioning as a registered group, plan events, reserve rooms, create and post flyers, the same system must be used. This system creates a public event and shares this event with police, fire, and risk management the moment a group tries to reserve a space. There is no freedom for extemporaneity or last-minute events. Noncampus organizations such as pro-life organizations, religious groups, or environmental groups can just show up and talk about their issues, but registered student groups must go through a long documentation process to have an organized presence on campus. Students and faculty agree these systems, present to some extent on all campuses, have killed the spontaneity in registered student group activism on campus (Dolhinow 2017).

This level of control does not go over well with the more radical groups. In the words of a student that works with Commit to Campus Justice, they are not registered with the university because,

When you become an org...you're much more visible. It's much more difficult to go ahead--you almost have to lay out everything in front of them before you do anything. I mean, not really, but certainly the administration has more access to what you're doing and all those kinds of things, and I don't think that we were feeling really comfortable letting the enemy (laughs) in on what was going on. -Al

The same student explains that, "there are some advantages to being an organized [registered] org, but in many cases, we can use the orgs we do belong to go ahead and get the advantages we need without having to go ahead and expose ourselves to the administration." The advantages to which $\mathrm{Al}$ refers range from reserving rooms on campus, using campus printers and caterers, to securing funding for events. When Commit to Campus Justice or OutSpoken organizes events with registered clubs (even in name only) they use relationships with campus allies to access the perks of registration but also continue to avoid exposing themselves and their strategies to the administration. In this way, they retain the freedom to act as they believe necessary.

Diana is a member of OutSpoken who also works in student government, which gives her special insight into student activism and student organizations on her campus. Here she weighs the pros and cons of registering as a student organization with an example she experienced as an OutSpoken member:

Yeah, they [unregistered groups like OutSpoken] can table wherever they want and not have that fear of being suspended. We can sit anywhere on their [university's] grass, pass out flyers. We can post in the restrooms if we want to post our flyers in the restrooms without a fear of getting called in. I know that I think it was last year in the fall [OutSpoken] put up a banner outside of the [blank] Building, and the dean of the college just so happened that she was walking past... and I was there. And, I was doing something [student government] related, and so she knows I am an [OutSpoken] member...And, she said, "You know, I don't mind the banner," she said, "but it can be dangerous if it falls because it's really windy today." And so, I think it's being held with, like, a 2-liter Pepsi bottle or something attached to something, and so I said, "Okay, I understand. I'll contact [OutSpoken] members and let 
them know." And, that's it, and so I think that if they would have been registered, they might have done something else and called [Student Affairs] and then sent an email and, you know, I don't know, some type of 'professional threat' is what I call it.

When Diana called the possible disciplinary action a "professional threat," she summed up the neoliberal mentality toward student activism: it must be professionalized to be controlled. She also draws attention to the more casual and lenient relationship administrators can take with unregistered groups.

Coming from the vantage point of a non-registered group gives student activists a flexibility and power that even the administration admires at times. Non-registered groups can say what needs to be said while administrations must censor registered groups and themselves. According to Amy from OutSpoken, this was the case after the election of Donald Trump, when her group put a poster over a school sign: "We covered up that [university name] sign. We didn't get permission from anybody. Did Admin come out? Yeah. Did they sit and look at it? Yes. Did they say, 'Good job.' Yeah." The goals of non-registered groups often align with those of staff in the Division of Student Affairs. Many of the staff in this Division have similar ethnic and cultural backgrounds as well as a history of social justice work or degrees that focus on social justice education. For these staff members, the similarities in their political and personal lives, outside the norms of the corporate university, make groups like OutSpoken natural allies and resources. This can become a very complicated relationship. In Amy's words:

They would say things like, 'You're saying things that I want to say but I can't.' I literally had like directors from [student center] say things like, you know 'I work for [ University President], so I can't say what I really think about xyz.' Yeah, yeah, so, I think in a way some people who work in administration wanted to utilize us.

Amy continues,

[s]o, I remember one time I got a call from Dr. [X] and she says, 'Tomorrow pro-lifers are coming to campus. Can you help us?' Like, like fucking superheroes (laughs). Like she sounded like a Batman call.

In this case, the administrator was able to use OutSpoken to oppose an undesirable demonstration taking part on campus. Yet, it was only because OutSpoken was not registered that they felt comfortable setting up a counter demonstration without any reservations for the space or prior permissions. The administrator knew only a nonregistered group could pull this off. This paradox is one of the most complicated aspects of researching radical student activism. As the neoliberal corporate university expands, it loses tolerance for non-structured and non-supervised forms of resistance. But dissent is sometimes still encouraged because many of the staff and administrators share values of social justice and visions for social change with the very groups they work to control. While Student Affairs Divisions typically do the work of dismantling Commons Counter Spaces, individual staff may be mentors for radical activists. This is why many radical activists bother to work to change to the system: they see the openings.
The history of unregistered student group activism in California is not lost on these activists working to change the system. In the late 60 s and early 70 s the California State University system was teaming with unaffiliated student activism. The Third World Liberation Front started at San Francisco State as a non-registered coalition demanding equal access to public higher education, more faculty of color, and, most famously, an ethnic studies curriculum. (Only this summer did California finally sign off on an Ethnic Studies graduation requirement.) At the same time at California State University Northridge, then called San Fernando Valley College, there was a series of massive demonstrations by the Alliance for Survival that led to hundreds of student and faculty arrests and culminated in the creation of the first Chicano Studies program in the California State University System. Like their predecessors, the current radical student activists educate their peers on campus, interact with student government and the administration, but they do not formally associate themselves with the university. Greg from Commit to Campus Justice had this to say on the topic:

I was just watching a documentary about CSUN, the protests in the late sixties.... Why do [they] have Chicano studies there, why do [they] have even a diverse school there? It's because of extreme conflict between nonregistered organizations of students, who are extremely grassroots and their administration. So, if we look back today, administrators will say, "I love Chicano studies; I love pan-African studies; these are my favorite things about us. We're such a diverse campus, upward mobility." What did it take to get those? Non-registered student orgs. How are they supporting us? We're a nonregistered student org. Wouldn't they want more things like that to come out of the social activities of students? Not really. They're afraid of them.

This knowledge of the history of student activism was fairly common in the non-registered clubs and quite often absent in registered ones. Perhaps this is so because nonregistered clubs attract more politicized student activists, who are curious about their choice to work outside the system and look to learn more, whereas campus-based registered groups are discouraged from examining the history of student activism in case it might politicize them in ways that are too challenging to their universities.

\section{Non-Affiliated Student Activism and the Bigger Picture Post COVID19}

When campaigns against police brutality have to be facilitated by student groups working outside their own universities, it is clear that the spaces of student activism on campus are severely compromised. If efforts to uncover racist enrollment policies and hold administrators responsible for the development of these policies must be organized off campus, any culture of disagreement, debate, and dissent is under attack. These activities, often central to student activism, are also the basis of critical political thinking. The problem is the discouragement of teaching students how to take action on their political ideas and the insignificant options for action offered on many campuses 
(Giroux 2015). Perhaps a hopeful space already exists in the "undercommons" proposed by Moten and Harney (2004), where subaltern ways of thinking and abolitionist politics might be able to rethink this institution in productive new ways. The undercommons is made up of both the space "where the work gets subverted" (p.102) and the community who are "in but not of" that space--in this case, radical student activists and their supporters. In this moment of opportunity, this could mean taking control of online/virtual learning and using the uncertain direction of higher education as an opportunity for dismantling and rebuilding curriculums, pedagogies, and the humanity of education in more equitable ways.

Another possible hopeful solution lies in virtual meeting spaces. The radical groups that already have networks and infrastructure off campus are leading the student activist movement in the California State University system during our current moment of virtual higher education, using zoom organizing to make change on campus from off campus. OutSpoken, for example, has been organizing virtually to question the response of higher education to the COVID19 pandemic. Each campus OutSpoken chapter holds their own Zoom meetings to survey their colleagues and understand the situation of their student body. They then take this data back to the statewide OutSpoken meetings via Zoom to develop plans for campaigns that facilitate communication with the administration at the state and campus levels. This method is creating strong movement on issues such as fee reimbursement and housing, giving students a voice to communicate with their administrations. The new spaces of virtual student activism that are being produced will be important models for the future of both affiliated and nonaffiliated student groups.

Faculty and administrators cannot afford to sit back, admiring the work of student activists and offering advice from their comfy office chairs, whether they are at home or on campus. As Greg from Commit to Campus Justice puts it,

Yes, faculty need to do a better job.... It's kind of like doctors with our private health care system. You know, fifty-five percent of them want mass public healthcare, what are they doing about it? They feel really comfortable and they have a lot of status as a doctor. They don't really see a reason to make a serious disruption in the system, even if they wanted to change.

If faculty and some administrators really want to see change, more involved support is necessary for student activists such as these.

The current global COVID19 pandemic is changing education as we know it. Many of these changes are onerous and tragic, but they also offer opportunities for positive movement as faculty, staff, and students are all learning how to work and organize from outside the physical university. To build future autonomous commons counter spaces and other anti-capitalist and non-corporate spaces on campuses, we will all need to work together to create spaces to "be-in-common" (Amsler 2017). To effectively draw on the theories of liberatory education that have come before us, we must first be able to share these theories in spaces that also allow us to discuss, practice, and integrate them. To do this faculty and staff may find they have to join student activists and do more work, physically and virtually, from outside, under, or beyond the neoliberal corporate system.

\section{References}

Amsler, Sarah. "What do we Mean When we Say 'Democracy'? Learning towards a Common Future through Popular Higher Education." In Out of the Ruins: The Emergence of Radical informal Learning Spaces, edited by Robert Haworth and John Elmore, 139-152. Oakland: PM Press, 2017.

Bollier, David. Think Like A Commoner: A Short Introduction to the Life of the Commons. Gabriola Island: new society Publishers. 2014.

Bousquet, Marc. How The University Works: Higher Education and the Low-Wage Nation. New York: NYU Press. 2008.

Dolhinow, Rebecca. "Activism on the Corporate Campus: It just doesn't have that you know what anymore", Australian Universities' Review 59, no.2 (2017): 14-22.

Dolhinow, Rebecca and Liz Sanchez. "Commodified dissent: The future of student activism?" SocietyandSpace.org. https://www.societyandspace.org/articles/commodified -dissent-the-future-of-student-activism (accessed April 30, 2020).

Ginsberg, Benjamin. The Fall of The Faculty: The Rise of the All-Administrative University and Why it Matters. New York: Oxford University Press, 2011.

Giroux, Henry. "Democracy in Crisis, the Specter of Authoritarianism, and the Future of Higher Education", Journal of Critical Scholarship on Higher Education and Student Affairs 1, no.1 (2015): 101-113.

Moten, Fred, and Stefano Harney. "The University and the Undercommons: Seven Theses", Social Text 22, no. 2 (2004): 101-115.

Kwon, Soo Ah. Uncivil Youth: Race, Activism, and Affirmative Governmentality. Durham: Duke University Press, 2013.

Newfield, Christopher. The Great Mistake: How we Wrecked Public Universities and How We can fix Them. Baltimore: Johns Hopkins University Press, 2016. (cc) EY-NC-ND

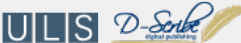

This work is licensed under a Creative Commons Attribution-Noncommercial-No Derivative Works 3.0 United States License. This journal is published by the University Library System of the University of Pittsburgh as part of its D-Scribe Digital Publishing Program, and is cosponsored by the University of Pittsburgh Press. 